Mediterranean Journal of Humanities

mjh.akdeniz.edu.tr

$\mathrm{I} / 2,2011,59-71$

\title{
Intercultural Communicative Competence in English (Foreign) Language Teaching and Learning
}

\author{
Ingilizce (Yabancı Dil) Ö̆̆gretimi ve Ö̆̆reniminde Kültürlerarası İletişim \\ Yeterliliği
}

\section{Uğur Recep ÇETÍNAVCI*}

\begin{abstract}
Based on a critical review of selected relevant studies and with a historical perspective, this review article as a piece of secondary research (Nunan, 1992, 8) aims to point out where the world of language teaching is in terms of the competences that learners are expected to gain. It was determined that intercultural communicative competence, i.e. the knowledge, motivation and skills to interact effectively and appropriately with members of different cultures (Wiseman, 2002, 208), is currently the highly favored one after the sequential dominance of grammatical (linguistic) competence and communicative competence. The major inference drawn from the review was that although a number of particular studies draw heavily on intercultural communicative competence, they are paradoxical or not clear about where and how they differ from the tenets of its criticized predecessor, i.e. communicative language teaching, and whose culture is to be taught along with the language. Taking sides for a pedagogical philosophy predicated on intercultural communicative competence, the author concludes that it is yet a set of beliefs and procedures in need of multidisciplinary research-driven clarification and maturation and in this respect, he refers to and discusses some fundamental principles and standpoints upon which a new model based on intercultural communicative competence can be built.
\end{abstract}

Keywords: Competence, intercultural communicative competence, foreign language teaching, teaching culture, intercultural communication

Özet: İlgili çalışmaların eleştirel ve tarihsel bir bakış açısıyla taranmasına dayalı olarak, bu çalışma İngilizce öğretiminin öğrencilerden beklenen yeterlilikler açısından nasıl bir noktada olduğunu ortaya koymayı amaçlamıştır. Dilbilgisi (gramer) yeterliliği ve iletişimsel yeterliliğin birbirini takip eden hakimiyetlerinin ardından, kültürlerarası iletişim yeterliliğinin (farklı kültürlerin mensuplarıyla etkin ve uygun bir biçimde etkileşime girmek için gereken bilgi, motivasyon ve beceriler [Wiseman, 2002, 208]) mevcut durumda ön planda tutulan yeterlilik türü olduğu görülmüştür. Ulaşllan başlıca sonuca göre, birçok çalışma kültürlerarası iletişim yeterliliğini temel almaktadır; fakat bu çalışmalar iletişimsel yeterlilik nosyonunun temel ilkelerinden nerede ve nasıl ayrıldıkları ve dille beraber hangi kültürün öğretileceği konularında ya çelişkilidir ya da net değildir. Yazar, kültürlerarası iletişim yeterliliğinin kazandırılmasına dayalı bir pedagojik felsefenin tarafı olarak, bu tür bir modelin henüz araştırmaya dayalı bir olgunlaştırma sürecine ihtiyaç duyduğu sonucuna varmıştır. Bu bağlamda, kültürlerarası iletişim yeterliliğinin üzerine inşa edilebileceği yeni bir model üzerine bir takım temel ilkeler ve bakış açıları ilgili atıflar desteğinde tartışılmışıtır.

Anahtar Sözcükler: Yeterlilik, kültürlerarası iletişim yeterliliği, yabancı dil öğretimi, kültür öğretimi, kültürlerarası iletişim

\footnotetext{
* Lecturer, English Language Teaching Department, Uludağ University, Bursa, Turkey, cetinavci@uludag.edu.tr
} 


\section{Introduction}

Being an obvious fact which one would naturally acknowledge, any foreign language teaching/ learning program, course, process or experience is at least officially and/or theoretically aimed to make its learners competent enough to use the target language for effective communication and/or problem solving. As a practice that started hundreds of years ago almost all over the world, language teaching has always been in a quest for the best way to achieve the abovementioned aim although, up until a certain period, those competences were not named, defined and declared in terms of their content, scope and constructs. It took years for linguistics first and then foreign language teaching to become established and institutionalized as independent and interrelated domains of science that conceptualize and explain language itself as a system and language teaching and learning as interwoven experiences.

\section{Linguistic Competence}

Throughout this long journey, Chomsky (1965) can be deemed to be the pioneer to provide us with the opportunity to consider language learning and production in terms of competences. He emphasized the study of language as a system in isolation and independent from any given context where the language is to be used, from which the Chomskyan concept of linguistic (grammatical or formal) competence emerged. As Alptekin $(2002,57)$ mentions, it refers to the native speaker's knowledge of the syntactic, lexical, morphological, and phonological features of the language, as well as the capacity to manipulate these features to produce well-formed words and sentences. It provides the linguistic basis for the rules of usage, which normally provides accuracy in comprehension and performance by virtue of the set or system of internalized rules about the language that enables a speaker to create new grammatical sentences and to understand sentences spoken to him, to reject "the ate goldfish John" as un-English and to recognize that "flying planes can be dangerous" is an ambiguous statement (Paulston, 1974, 350).

As Paulston $(1974,348)$ reports, a very large part of the criticism leveled against Chomsky concerns the inadequacy of his attempts to explain language in terms of the narrow notions of the linguistic competence of an ideal hearer-speaker in a homogeneous society. Such a speaker is likely to become institutionalized if he/she simply produces any and all of the grammatical sentences of the language with no regard for their appropriateness (Hymes, 1972, 277) in terms of the contextual variables in effect.

\section{Communicative Competence}

Demonstrating a clear shift of emphasis among scholars who work on language, Hymes (1972) coined and defined the term communicative competence as the knowledge of both the rules of grammar and the rules of language use appropriate to a given context. As reported in Alptekin (2002) and Uso-Juan and Martinez-Flor $(2008,158)$, Hymes's conceptualization of communicative competence has been further developed by several researchers who attempted to define the specific components of the model as grammatical competence (i.e. knowledge of the language code in a way that refers to Chomsky's linguistic competence); sociolinguistic competence (i.e. knowledge of the sociocultural rules of use in a particular context); strategic competence (i.e. knowledge of how to use communication strategies to handle breakdowns in communication) and discourse competence (i.e. knowledge of achieving coherence and cohesion in a spoken or written text). Pragmatic competence is essentially included in this model under sociolinguistic competence, which Canale and Swain $(1980,30)$ described as 'sociocultural rules of use'. Being grounded on this taxonomy, communicative competence was repeatedly divided into some lesser known sub-competences like physiological mechanisms (Bachman, 1990) and actional competences (Celce,-Murcia, Dörnyei, \& Thurrell, 1995). 


\section{Intercultural Communicative Competence}

As Robatjazi $(2008,250)$ postulates; communicative competence draws on how a foreign or second language learner uses his foreign/second language command and what he in different settings and interactions utters as appropriate. However, the idea that emerged in the aftermath was that communicative language teaching had ignored some important facts, which are that communication had to be understood as more than just a simple information and message exchange between interacting people through language use and linguistic awareness, even if it is contextualized, may not be sufficient, unless it is combined with multidimensional cultural awareness. As any encounter with Otherness -whether national, racial, or ethnic- is always experienced as a challenge to the existing beliefs, values, and behaviors of people (Skopinskaja, $2009,135)$, it was seen that this challenge may have a twofold effect, leading either to a confrontational relationship with the Other, in which Self and Other are experienced as incompatible; or leading to a relationship of acceptance where Self and Other are trying to negotiate a cultural platform that is satisfactory all the parties involved (Guilherme, 2000). These ideas engendered the notion of intercultural communicative competence, whose definition can be, "the knowledge, motivation and skills to interact effectively and appropriately with members of different cultures", (Wiseman, 2002, 208) and whose component elements can be the qualifications and skills required of "the sojourner" (Byram, 1997), who are defined as migrants whose goal is to return with wealth to their native land (Ball, \& Lau, 1966). In this regard, being a scholarly book about the experiences of four Japanese sojourners in the US and Canada, Kanno's (2003) work and its participants' communicational failures even when fluently speaking the needed language can now be interpreted in a new light.

Following the emergence of the notion of intercultural communicative competence and its relations to (foreign language) education, many studies have been produced concerning different scopes and focal points. Questioning what makes a learner's communicative competence in English and hypothesizing that it cannot be accomplished without having an orientation towards the other's culture, Akalin (2004) examined with an intercultural eye the textbooks used in Turkey to teach English. Based upon her findings, she suggests that textbooks for especially young learners should firstly be predicated on characters, pictures, illustrations, texts and subjects from Turkish and even local culture and move slowly to the target culture and to crosscultural experiences so that students would not feel inhibited and strange as we proceed from the simple to the more complex and from known to the unknown in any educational process. In order for this to happen, she proposes as a solution that large foreign publishing companies should communicate with each target nation's English teachers and educationalists.

Emphasizing the fact that the objective of language learning is no longer defined in terms of the acquisition of communicative competence in a foreign language but rather in terms of intercultural competence, which is "the ability of a person to behave adequately in a flexible manner when confronted with the actions, the attitudes and the expectations of the representatives of foreign cultures" (Meyer, 1991, 138). Similarly, teachers are now expected not only to teach the foreign linguistic code but also to "contextualize that code against the socio-cultural background associated with the foreign language and to promote the acquisitions of intercultural communicative competence" (Castro, 1999, 92). Atay, Kurt, Çamlıbel, Kaşlıoğlu and Ersin (2009) investigated the opinions and attitudes of Turkish teachers of English on intercultural competence teaching to see how, and to what extent, these opinions and attitudes are reflected in their classroom applications. The researchers found that, like Polish, Spanish, Swedish and Belgian teachers in Sercu and others' study (2005) and that on Spanish secondary school EFL teachers completed by Castro, Sercu and Garcia (2004), the participants defined the objectives of foreign language above all in terms of the acquisition of the ability to use the foreign 
language for practical purposes and prioritized language teaching objectives over culture teaching objectives. Regarding the objectives of culture teaching, the finding is that Turkish EFL teachers favored the knowledge of "providing information about daily life and routines" more than information about the foreign culture, history, geography and political conditions. The authors attribute this to the probability that teachers associated cultural information with communication. This finding may be a trace of the relationship between intercultural competence and communication competence being dominated by communicative skills rather than the general educational objectives which might be associated with history, geography and political issues. Another interesting result of the study is that the teachers expressed strong support to "help students understand their own cultures better". This finding is ascribed by the authors to the fact that the teachers were not familiar enough with the target language cultures, did not have much contact with English speaking people, and did not feel fully knowledgeable about the target culture, and thus felt more comfortable focusing on the students' and their own native culture. Finally, the teachers appeared not to be integrating culture-related classroom practices in their own classes frequently, although they are reported to have positive attitudes towards the role of culture in foreign language education. According to the researchers, this might be due to the fact that they do not know and, thus lack the training on, how to integrate culture into their own classes. As for the educational implications of the study, it is emphasized that teacher education programs should include a cultural aspect in their curricula, such as a course on intercultural communication, in order to equip prospective teachers with intercultural awareness and intercultural competence so that they will eventually be more able to integrate cultural practices into teaching.

Penbek, Yurdakul and Cerit (2009) carried out a study motivated by the fact that today business is conducted across the borders of one nation, which makes the world as a whole an economic and political marketplace (Hugenberg, LaCivita, \& Lubanovic, 1996). In this respect, they attach great importance to intercultural communicative competence, which is more than just being able to speak the language of the receiver in the communication process. It is rather to know as much as possible about the receiver in order to increase the efficiency of international communication. This requires knowing the background of the people, where they grew up, what they care about, how they react and so on. Coping with people from different cultures, in brief, requires more than a language (Penbek et al., 2009, 2) as is verified in the interaction between the Hong Konger and American businessmen in Scollon and Scollon $(2000,122)$ where these two unintentionally and pathetically produced maybe the wrongest words and actions possible, while supposing that they are considerately producing the most proper ones. The perspective in Penbek et al.'s study (2009) transcends elementary and high school foreign language classrooms and focuses on the impact of "university education" and "intercultural experience" on the level and strength of intercultural communicative competence. The researchers view especially university education and exchange programs like Erasmus as highly critical in having intercultural sensitivity to understand, work, live and deal with cultural differences in today's global work environment, where multinationals eagerly seek for new graduates with intercultural competence to work either at home or abroad. In this regard, they tried to interpret whether the students from different departments have developed the required level of intercultural sensitivity and selfperceptions to develop better intercultural communication across nations. They found that departments providing education supported by international materials such as simulations, exchange programs, internship experience, language courses and online sources will help to educate graduates equipped with sufficient intercultural sensitivity to develop mutual respect with people from other cultures.

Asserting that communicative competence, with all its aforementioned sub-competences 
would remain incomplete without intercultural competence as the approach less taken in the language classes; Uso-Juan and Martinez-Flor (2008) provide a variety of activities in four language skills to equip learners with intercultural communicative competence.

The first step is explanation, i.e. explaining to learners the concept of intercultural competence in order to make them aware of the importance of paying attention to the culture of the target language. They are presented with a list of key areas that offer the possibility for developing intercultural competence, including family, education, law and order or power and politics among others. In the second step, i.e. collection, learners are given the task to gather material outside the classroom in relation with the cultural topics they have agreed to work upon (photocopied information from different printed materials, photo-documentaries, pictures, video or DVD scenes, recorded material like interviews with native speakers, excerpts from the Internet etc) so that their cultural awareness is further increased through having to question themselves as to what is culturally representative of the given topic. In the third stage, i.e. Implementation, learners work with a variety of activities that require their use of the four skills (i.e., listening, speaking, reading and writing) to develop their overall communicative competence, and promote their cross-cultural awareness and understanding.

For listening skill, video-taped cultural dialogues, audio or video-taped intercultural misunderstandings, recorded interviews with native speakers and exemplary films, TV programs, songs, jokes or anecdotes from the target culture can be cited as some example activities.

For speaking skill, face-to-face tandem learning (in instructional settings with the Erasmus scheme for example, teachers arrange opportunities for all learners to get engaged in face-toface tandem, and once learners have got to know their international partners and have arranged the time and place for the tandem sessions, they are asked to choose a particular cultural topic among those dealt with in the project and talk about it with their corresponding partners), making up questions for a native speaker visiting the classroom, role-playing suitable for practicing the cultural variations in speech acts such as apologizing, suggesting, complimenting and others, and nonverbal videos, to have learners act out or describe what they view can be mentioned as some of the sample activities.

For reading skill, critical reading, that is, reading to make judgments about how a text is argued and how the text portrays the given topic, reading situations in which there is a cultural bump, analyzing two written texts which have a similar genre, reading advice columns for example in daily newspapers but which are from different cultures, giving scrambled sentences of a cultural anecdote to help learners discern the organizational issues in a given text and previewing or making guesses about the content of a given cultural text both before, and while reading, are some of the sample activities.

When it comes to writing skill; tandem e-mail learning, in which learners from different cultures first introduced themselves and they are then requested to engage in a written dialogue based upon a given cultural topic and designing stories based upon a variety of pictures and/or videos that depict people in attention-grabbing situations in the target culture are among the sample activities.

Departing from the fact that communication in real situations is never out of context and because culture is a part of context, communication is seldom culture-free, Robatjazi $(2008,247)$ refers to Kramsch (1993) and Valdes's (1986) emphasis on the inseparability of language learning and learning about target cultures and he posits that foreign language learners should become interculturally aware of both their own culture and, more importantly, that of others; otherwise, they will interpret the foreign language messages based upon their own cultures, whose intended meanings might well be interpreted on different cultural grounds and frameworks. In this regard, Robatjazi (2008) mentions and bases his study on the expectation from EFL and/or ESL 
curriculums and materials that they will reflect a range of cultural contexts and include intercultural elements so that students' intercultural awareness and conceptualizations are elevated for the sake of successful and effective communication.

In terms of curriculum planning, syllabus design and material development; Robatjazi (2008) places the responsibility on competent and unbiased curriculum designers, material writers, teachers and learners (who are aware of their own needs and interests) for determining the order in which students encounter and hopefully acquire different aspects of intercultural communicative competence from teaching materials like textbooks, which reflect a worldview or cultural system indirectly constructing the teachers and the students' view of a different culture, i.e. another world. As for the content of teaching materials, the author is a proponent of authenticity defined as presenting, "real language created by native speakers of the language in pursuit of communicative outcomes (Little, Devitt, \& Singleton, 1989). In planning the curriculum on the other hand, besides some particular universal and general grounds upon which all academic communities with different cultures can base their foreign/second language policies, Robatjazi (2008) indicates that the geo-political context, the learning context and the developmental factors and objectives of the learners should all also be taken into account in any given situation.

According to the author, the concept of progression is important in a curriculum that takes intercultural communicative competence into consideration. Warning that a progression to lead to such a competence would not be a linear and cumulative one, but in a way clarified with the metaphor of completing a jigsaw puzzle, where the early stages have provided the edges and corners and at later stages the learners, sometimes with the help of teachers, gradually complete elements of the whole picture without necessarily making connections among them until the picture is completed. His suggestion is that stereotypes of the people whose language is being taught can be included in the early stages and more complex and analytical portions like relations and affections can be postponed to the later levels. In addition to the issues of progression; Robatjazi (2008) adds the necessity that "a threshold of intercultural communicative competence" should be integrated into the curriculum, whose definition is made as follows: one has reached the threshold when he/she is able to communicate with others successfully, when he/she can easily get his ideas across and leaves no burden of misinterpretation or misconception due to his/her own cultural unawareness.

All the studies mentioned so far are motivated by the shortcomings and deficiencies of the communicative competence model mainly because it sees successful communication between people from different cultures as principally a matter of using linguistically appropriate constructs in given contexts ignoring the need for cultural awareness and sensitivity in a world where countless people with different identities and first languages engage in countless interactions every day in numerous forms via English. In this regard, the studies in question try to show some ways so that language learners can have intercultural communicative competence after being trained with an eye to the cultural aspects that they might need to consider in their future interactions with speakers of the language(s) that they are learning. However, as a piece of secondary research, which consists of reviewing the literature in a given area and synthesizing the research carried out by others (Nunan, 1992,8) to serve as a prerequisite to primary research in the form of case and/or statistical studies (Nunan, 1992), the central thesis of the current study is that although most of the aforementioned studies refer to the fact that the world now is a global village where numerous different languages and cultures can meet and interact at any moment, they tend to show a particular culture as the one which language learners need to be aware of and that particular culture seems to be either the British or American culture, having English, the lingua franca of our day, as their native language. They say a lot worthy of our thought and attention about taking culture into account while teaching the language but their 
valuable advice seem quite hard to follow without referring to a particular society and/or culture in the myriad of authentic communication situations likely to emerge at any time with a great many sociocultural variables in our globalizing world. For this reason, their eventual message in practical terms can be considered not distinctly different from those of the communicative competence model and especially its subcomponent of sociolinguistic competence, which is the ability to adjust one's speech to fit the sociocultural situation in which it is spoken (Mizne, 1997). At this point, the view should be mentioned that the communicative competence model and the materials it makes use of, have a tendency to teach about such sociocultural situations with a monolithic perception of the native English speaker's culture, by referring chiefly to mainstream ways of thinking and behaving (Alptekin, 2002).

In this regard, it is possible to mention that Alptekin's (2002) study is one step further. First of all, he voices the severest criticism against the communicative competence model. He questions the extent to which a language learner is supposed to be communicatively competent. As the model and its materials tend to show an idealized figure of native English speaker-listener as the reference point, Alptekin asks the question "Who is this 'real' native speaker-listener that typify accurate and proper language use, if he/she is not a myth?" and continues that what British and American textbooks do is create and perpetuate some stereotypes and so produce an idealized form of English. His rationale is the fact that English like other languages has several dialects and one cannot claim that there is one correct and appropriate way to use English, in the sense that one set of language patterns is somehow inherently superior to all the others. In addition, he asserts that as early as 1985 the number of people who used English worldwide either as their native or non-native language was one and a half billion and within a short period of time the number of people who speak English as a non-native language may well exceed the number of all kinds of its native speakers, let alone those like the idealized stereotypes in the abovementioned teaching materials. What is more, Alptekin (2002) claims that this utopian view of the model restricts the teacher's and the learner's autonomy and leads a considerable number of ELT educators to train their students to 'act' in English, as they are believed to 'need to become English-speaking people, different from the people who speak their native language, assuming the body language, intonation, and life view of English speakers' (Latulippe, 1999). Obsessed with the authenticity of the language presented in the classroom, which is one of the tenets of the communicative approach, educators intentionally or not refers to what current textbooks have to offer as the authentic language, which are either native speaker-native speaker or native speaker-non-native speaker interactions. He draws attention to how groundless and inappropriate these tendencies are by emphasizing the fact that, given the lingua franca status of English, it is clear that much of the world now needs and uses English for instrumental reasons such as professional contacts, academic studies, and commercial pursuits and in this context, much communication in English involves (and will increasingly involve) non-native speaker / nonnative speaker interactions. Then Alptekin (2002) asks and the author believes that we as educators should ask: "How relevant are the conventions of British politeness or American informality to the Japanese and Turks, say, when doing business in English? How relevant are such culturallyladen discourse samples as British railway timetables or American newspaper advertisements to industrial engineers from Romania and from Egypt conducting technical research in English? How relevant is the importance of Anglo-American eye contact, or the socially acceptable distance for conversation as properties of meaningful communication to Finnish and Italian academicians exchanging ideas in a professional meeting?.

With regard to the considerations noted above, Alptekin (2002) posits that there is an absolute need for a radical rethink in terms of a modified and expanded definition of the traditional notion of communicative competence and real communicative behavior ought to be reconceptualized 
in relation to the reality of English as an International Language beyond the monopoly of its one or two communities of native speakers. Recognizing the international status of English and challenging the view that teaching English would automatically entail teaching about some imposed British and American cultural norms, the author argues that English should be taught as an international language, whose culture is the world itself. He adds that, in order for learners to use it as an international language in cross-cultural settings, a new pedagogical model is urgently needed to accommodate English as a means of intercultural communication. As the criteria to be taken into account in this model, Alptekin (2002) provides the following:

1) Successful bilinguals with intercultural insights and knowledge should serve as the pedagogic models for English as an International Language (EIL) rather than the monolingual native speaker.

2) Intercultural communicative competence should be developed among EIL learners by equipping them with linguistic and cultural behavior which will enable them to communicative effectively with others, and also by equipping them with an awareness of difference, and with strategies for coping with such difference (Hyde, 1998).

3) The EIL pedagogy should be one of global appropriacy and local appropriation, in that it should prepare learners 'to be both global and local speakers of English and to feel at home in both international and national cultures' (Kramsch, \& Sullivan, 1996, 211).

4) Instructional materials and activities should involve local and international contexts that are familiar and relevant to the language learners' lives.

5) Instructional materials and activities should have suitable discourse samples pertaining to native and non-native speaker interactions, as well as non-native to non-native speaker interactions. Discourse displaying exclusive native speaker use should be kept to a minimum, as it is chiefly irrelevant for many learners in terms of its potential use in authentic settings (Widdowson, 1998).

In specific reference to and support of Alptekin (2002) based upon direct experience and observation from Japan, Samimy and Kobayashi (2004) strongly object to the current implementations of communicative English teaching in the country claiming that they were imposed upon with a top-down approach by political and bureaucratic authorities on the assumption that any idea that seems to work in the U.S. and the U.K. and/or EFL contexts should work equally well in countries like Japan and/or any ESL context. While the Japanese education system like the one in Turkey is characterized by crowded classrooms and masses of students associating the study of English with the university entrance exams, which emphasizes grammar, vocabulary and reading comprehension, the authors question how reasonable it is to recruit native speaker English teachers (which is a hot controversial issue at present in Turkey too) and force Japanese English teachers to fill students with Western values embedded in Communicative Language Teaching, such as the relative importance of process as opposed to content and the emphasis on meaning over form (Ellis, 1996) and native English or American linguistic and sociolinguistic norms. In conclusion, Samimy and Kobayashi argue that in educational contexts like the one in Japan with limited access to English, learners' restricted communication needs, non-native teachers, a different culture of learning, and the dominance of university entrance examinations, Communicative Language Teaching should be embraced in a culturally sensitive and appropriate way maintaining the contextual autonomy with a paradigm shift that emphasizes intercultural communicative competence.

As a study with a fairly different perspective, Garcia and Biscu (2006) can be cited here. It is about the introduction of a new course called "Language Mediation" at the School for Interpreters and Translators of the University of Bologna, which is a project to teach intercultural communicative competence through theatre. The idea emerged from the Council of Europe's 
definition of "mediation" as a communicative activity of the language user/learner, thus the undergraduate interpreter/translator as well, in which s/he acts as an intermediary between interlocutors who are not able to understand each other. In pursuit of what constitute a language mediator's competences and skills, the authors found that he/she, besides language competence, should also possess sociolinguistic, discursive, strategic and sociocultural competence (Oliveras, $2000,24)$ and intercultural communicative competence (Rodrigo, 1999, 235) comprising verbal and non-verbal aspects of communication, intercultural awareness and the mastery of pragmatics, behavioral patterns and negotiation (Oliveras, 2000). In this context, the authors were inspired by the belief that theatre is a means to achieve the awareness and knowledge necessary to experiment intercultural exchanges, since the re-expression of a dramatic text in a foreign language -in with other space and another time- leads to dialogue with the mental context of the other culture.

In the first stage of the project, dramatic texts are to be chosen following Balboni's (1999) identification of six domains for the observation of cultural patterns, namely 'social relationships', 'social organization', 'home and family', 'city', 'school' and 'mass media' with sub-domains like immigration, religion, the health service, parents-children relationships, power statuses, the role of families in school, communication and silence, the importance of time, giving presents, etc. Then, teaching activities are to be devised based upon behavior observation, text analysis, stereotype identification, account of misunderstandings, study of idioms, etc in classroom and for practical applications on the stage. The second stage consists of the analysis of the research data on the acquisition of competences through appropriately designed and triangulated evaluation questionnaires/interviews and the interpreting of the results. The third and last stage of the project is the creation and publication of an interactive CD-ROM containing thematic teaching units, extracts taken from the multilingual corpus of dramatic texts, a guide for teachers and students, information about the authors of the dramatic texts selected, analysis of the linguistic, historical, social and cultural aspects of the dramatic texts, exercises for the classroom (curricular training) and for the theatre workshop (extracurricular training) and some examples of theatre translations made by students at the second research stage. In this respect, the ultimate purpose of the research project is declared to be providing the necessary background for developing empathy and accepting the other, since students discover that the other is hidden under their own skin.

Linguistically speaking, we can mention that the project provides learners with authentic language so that they can engage with it as discourse as it localizes language within a particular discourse community (Alptekin, 2002), i.e. students of Spanish as a second language, registered for a degree at the School for Interpreters and Translators work on dramatic texts in Spanish for example. In this way, ambiguity is removed as to what cultural aspects are intended when declaring that it is a syllabus targeting (inter)cultural sensitivity, awareness, competence etc.

\section{Conclusion}

Researchers, educationalists, theoreticians, teachers and students in the world of language teaching have long sought answers to questions such as, "what competence/competences does a language learner need to have?" and the answers gaining general acceptance have shaped and steered the relevant pedagogical approaches, methods, actions and materials. In this journey, communicative language teaching and the competences involved in it seem to comprise the last broadly conceived, systematized and implemented pedagogy. It can be discussed whether learning about a culture along with the language is an imperative but as it would be hard to deny the fact that cultural awareness and knowledge would facilitate and protect interpersonal communication, the communicative approach especially with its component of sociolinguistic competence can be mentioned as the first to take the cultural dimension of language learning into demonstrable consideration. 
However, a review of the pertinent literature suggests that the model receives considerable criticism and suspicion especially in recent years mainly because it falls short of accounting for authentic communication situations and needs in the cross-cultural settings of the globalizing world, where English as an international language is the means of communication between people from almost all cultural and/or linguistic backgrounds. The source of criticism is that the model, directly or not, imposes the culture of the major Anglophone countries as the one to be learnt in conjunction with English while an average language learner of our day may use English without any encounter with an Englishman, for example, in his/her entire life. Then one of the relevant questions can be "Why prepare and use a textbook laden with the sociocultural norms of England and/or the USA?".

Such criticisms and questions have brought about the pursuit of a new pedagogical approach and redefinition of the competences that language learners need to display. We can say that intercultural communicative competence is an impressive result that the pursuit in question has produced. However, we see that this model is not as yet well-established and structured. At this point, the title of Alptekin's (2002) study, which was published in a highly prestigious journal in the field as the most influential study among the ones cited here, deserves careful attention. It is entitled, "Towards Intercultural Communicative Competence in English Language Teaching", which suggests that we still have a considerable distance to cover to reach a full-fledged new model. As of now, like Alptekin's (2002) mentioned above, we can talk about some principles that can serve as a general framework and basis for the model.

As cited in Penbek et al. $(2009,2)$; if an educational process is to make the learners interculturally competent, it should help them change their knowledge, attitudes and behaviors so as to be open and flexible to other cultures in the globalized society of the $21^{\text {st }}$ century (Alred, \& Byram, 2002). In order to achieve that openness and flexibility, as Penbek et al. $(2009,3)$ report, the summary of the relevant literature indicates that being interculturally competent communicators takes communication competence (the ability to effectively and appropriately execute communication behavior to elicit a desired response in a specific environment [Chen, 1990]), intercultural awareness, personal attributes (display of respect, interaction posture, orientation to knowledge, empathy, role behaviors, interaction management and tolerance of ambiguity [Ruben, 1976]), psychological adaptation, social skills and perception. These are supported and in a way reiterated by Savignon $(2002,10)$ asserting that the success of communication with a general empathy and openness toward other cultures hinges on the "negotiation of meaning" and the "willingness to suspend judgment and take into consideration the possibility of cultural differences" among those involved, rather than upon the adoption of native English linguistic and sociolinguistic norms.

It is clear that teaching materials occupy an important place in the development and establishment of a new model based upon intercultural communicative competence. In addition to his other remarks on the issue, Alptekin $(2002,60)$ postulates that only by producing instructional materials that emphasize diversity both within and across cultures can one perhaps avoid presenting English meanings in fragmented and trivialized ways. Taking a skeptic point of view on the communicative approach pushing toward the use of authentic materials, McKay $(2002,100)$ stresses the use of materials that include the learners' culture, the target culture, and international culture. She asserts that the materials should be used in such a way that students are encouraged to reflect upon their own culture in relation to others, thus helping to establish a sphere of interculturality.

As is seen, if it is time for English language teaching to consider the implications of the international status of English in terms of appropriate pedagogies and instructional materials to create successful intercultural individuals (Alptekin, 2002, 63), English language courses need 
to promote awareness of the different cultural values underlying languages so as to encourage students to become cultural observers and analysts, discovering the territory and drawing the map for themselves. Teachers provide an outline and students fill it in (Fitzgerald, 2003), which shows that teachers and teacher education on their own are a significant factor in need of being meticulously considered and researched in terms of reaching intercultural communicative competence. Another crucial issue to put on the related further research agenda is how to test and assess intercultural (communicative) competence (Sercu, 2005; Skopinskaja, 2009).

The tasks to be accomplished on the route to developing such a model as the one described above imply that the community of English language teaching and research has a lot to do. Nonetheless, the author believes that it would not be fair to expect solely from English language courses, teachers and materials to give individuals such aforementioned personal attributes as display of respect, interaction posture, orientation to knowledge, empathy, interaction management, tolerance of ambiguity etc., and even a properly structured system of intercultural competenceoriented English language education would not suffice unless it is backed up by a broader research-driven educational philosophy and a multidisciplinary policy embracing openness to other cultures within the framework of a keen appreciation of the importance of intercultural communication in our globalizing world.

\begin{abstract}
About the Author
Uğur Recep Çetinavcı is a lecturer at Uludağ University, Faculty of Education, Department of English Language Teaching, Bursa, Turkey. He studied English language and literature at Ankara University. He worked as an English teacher at a state high school and a military vocational school. He had his MA degree on English language teaching at Uludağ University in 2004 and has taught English, Contextual Grammar and Poetry Analysis and Teaching there since then. At present, he is doing his doctorate at Çanakkale 18 Mart University.
\end{abstract}




\section{REFERENCES}

Akalın, S. (2004). Considering Turkish students' communicative competence in teaching English communicative competence. Atatürk University Journal of Graduate School of Social Sciences, 4(2), 227-237. Erzurum.

Alred, G., \& Byram, M. (2002). Becoming an intercultural mediator: A longitudinal study of residence abroad. Journal of Multilingual and Multicultural Education, 23, 339-352. Clevedon: Multilingual Matters.

Alptekin, C. (2002). Towards intercultural communicative competence in ELT. ELT Journal, 56(1), 57-64. Oxford.

Atay, D., Kurt, G., Çamlıbel, Z., Kaşlığlu, Ö., \& Ersin, P. (2009). The role of intercultural competence in foreign language teaching. Inonu University Journal of the Faculty of Education, Special Issue, 10(3), 123-135. Malatya.

Balboni, P. E. (1999). Parole comuni, culture diverse. Guida alla comunicazione interculturale. Venezia: Marsilio.

Ball, J. C., \& Lau, M. P. (1966). The Chinese narcotic addict in the United States. Social Forces, 45, 68-72. Chapel Hill.

Byram, M. (1997). Teaching and assessing intercultural communicative competence. Clevedon, UK: Multilingual Matters.

Canale, M., \& Swain, M. (1980). Theoretical bases of communicative approaches to second language teaching and testing. Applied Linguistics, 1(1), 1-47. Oxford.

Castro, P. (1999). La dimensio'n europea en la ensen ${ }^{\sim}$ anza/aprendizaje de lenguas extranjeras: La competencia intercultural. Lenguaje y Textos, 13, 41-53. A Coruña.

Castro, P., Sercu, L., \& Garcia, M. C. M. (2004). Integrating language-and-culture teaching: An investigation of Spanish teachers' perceptions of the objectives of foreign language education. Intercultural Education, 15(1), 91-104.

Celce-Murcia, M., Dörnyei, Z., \& Thurrell, S. (1995). Communicative competence: A pedagogically motivated model with content specifications. Issues in Applied Linguistics, 6(2), 5-35. Cambridge.

Chen, G. M. (1990). Paper presented in the Annual Meeting of the Eastern Communication Association: ICC: Some Perspectives of Research. Philadelphia.

Chomsky, N. (1965). Aspects of the theory of syntax. Cambridge, MA: MIT Press.

Ellis, G. (1996). How culturally appropriate is the communicative approach? ELT Journal, 50(3), 213-128. London.

Fitzgerald, H. (2003). How different are we? Spoken discourse in intercultural communication. Clevedon: Multilingual Matters Ltd.

Garcia, M. I. F., \& Biscu, M. G. (2006). Theatre in the acquisition of intercultural communicative competence: The creation of a multilingual corpus of dramatic texts for the training of future language mediators. International Journal of Learning, 12(10), 327-336. Altona

Guilherme, M. (2000). Intercultural competence. Ed. Byram, M. S., M. Routledge Encyclopedia of Language Teaching and Learning. 298-300. London and New York: Routledge Taylor and Francis Group.

Hyde, M. (1998). Intercultural competence in English language education. Modern English Teacher, 7(2), 7-11. London.

Hymes, D. H. (1972). On communicative competence. Ed. Pride, J. B, \& Holmes, J. Sociolinguistics 269293. Baltimore: Penguin Books.

Hugenberg, L. W., LaCivita, R. M., \& Lubanovic, A. M. (1996). International business and training: Preparing for the Global Economy. The Journal of Business Communication, 33(2), 205-222. Urbana.

Kanno, Y. (2003). Negotiating bilingual and bicultural identities. Japanese returnees betwixt two worlds. Mahweh, NJ: Lawrence Erlbaum.

Kramsch, C. (1993). Language study as boarder study: Experiencing difference. European Journal of Education, 28(3), 349-358. Dorchester-on-Thames, Oxford. 
Kramsch, C., \& Sullivan, P. (1996). Appropriate pedagogy. ELT Journal, 50(3), 199-212. London.

Latulippe, L. (1999). Lessons learned from being a student again. TESOL Matters, 9(2), 13.

Little, D., Devitt, S., \& Singleton, D. (1989). Learning foreign language from authentic texts: Theory and practice. Dublin: Authentik.

McKay, S. (2002). Teaching English as an international language. Oxford: Oxford University Press.

Meyer, M. (1991). Developing transcultural competence: Case studies of advanced foreign language learners. Ed. Buttjes, D., \& Byram, M. Mediating languages and cultures, 138-158. Clevedon: Multilingual Matters.

Mizne, C. A. (1997). Teaching sociolinguistic competence in the ESL classroom. Senior Thesis Projects, 1993-2002. Retrieved on August 2011 from http://trace.tennessee.edu/utk_interstp2/20

Nunan, D. (1992). Research methods in language learning. Cambridge: Cambridge University Press.

Oliveras, V. Á. (2000). Hacia la competencia intercultural en el aprendizaje de una lengua extranjera: Estudio del choque cultural y los malentendidos. Madrid: Edinumen.

Paulston, C. B. (1974). Linguistic and communicative competence. TESOL Quarterly, 8(4), 347-367.

Penbek, S., Yurdakul, D. \& Cerit, A. G. (2009, July). Intercultural communication competence: A study about the intercultural sensitivity of university students based on their education and international experiences. European and Mediterranean Conference on Information Systems. Izmir, Turkey.

Robatjazi, M. A. (2008). Language education: Intercultural communicative competence and curriculum. Glossa, 3(2), 245-265. Burnaby.

Rodrigo, A. M. (1999). La comunicación intercultural. Barcelona. Rubí: Anthropos Editorial.

Ruben, B. D. (1976). Assessing communication competency for intercultural adaptation. Group and Organizational Studies, 1(3), 334-354. Newbury Park.

Samimy, K. K., \& Kobayashi, C. (2004). Toward the development of intercultural communicative competence: Theoretical and pedagogical implications for Japanese English teachers. JALT Journal, 26(2), 245-261. Kyoto.

Savignon, S. (2002). Interpreting communicative language teaching. New Haven, CT: Yale University Press.

Scollon, R., \& Scollon, S. W. (2000). Intercultural communication. A discourse approach. Oxford, UK: Blackwell.

Sercu, L. (2005). Testing intercultural competence in a foreign language. Current approaches and future challenges. BELL Belgian Journal of English Language and Literature, 3. 151-167. Ghent.

Sercu, L., Bandura, E., Castro, P., Davcheva, L., Laskaridou, C., Lundgren, U., Mendez García, M., \& Ryan, P. (2005). Foreign language teachers and Intercultural Competence: An international investigation. Clevedon: Multilingual Matters.

Skopinskaja, L. (2009). Assessing intercultural communicative competence: test construction issues. Synergies Pays Riverains de la Baltique 6, 135-144. Estonia.

Usó-Juan, E., \& Martínez-Flor, A. (2008). Teaching intercultural communicative competence through the Four Skills. Revista Alicantina de Estudios Ingleses, 21, 157-170. Alicante.

Valdes, J. M. (1986). Culture bound: Bridging the cultural gap in language teaching. Cambridge, UK: Cambridge University Press.

Widdowson, H. G. (1998). Context, community, and authentic language. TESOL Quarterly, 32(4), 705-716.

Wiseman, R. L. (2002). Intercultural communication competence. Ed. Gudykunst, W. B., \& Mody, B. Handbook of international and intercultural communication (2nd ed.), 207-224. Thousand Oaks, CA: Sage. 